\title{
FALA SÉRIO! - QUE IDEOLOGIA É ESTA? - FAVORÁVEL ÀS MULHERES É QUE NÃO PARECE SER - 20/12/20211
}

English Title: WHAT IDEOLOGY IS THIS? - FAVORABLE TO WOMEN IS THAT IT DOESN'T SEEM TO BE

doi>10.33726/akdpapers2447-7656v12a72021p89-91

PESSOA, Marcelo ${ }^{2}$

Eu que acreditava que não escreveria mais nada neste ano de 2021, fui compelido, pela Rede GLOBO de Televisão, a retomar a arte deste ofício.

$\mathrm{Na}$ data de 19/12/2021, domingo, em matéria exibida pelo FANTÁSTICO, a GLOBO veiculou uma matéria-debate sobre aquilo que seriam as "necessidades de masturbação das mulheres" que beiram os 50 anos de idade.

Ao ver o conteúdo, estranhei que tão elevado grau da intimidade feminina fosse assim, aberta e despudoradamente, colocado ao público geral, fazendo com o que, até então, dizia respeito a uma particularidade do comportamento humano, se tornasse objeto de interesse e de preocupação social ampla.

Usaram para tal exposição, inclusive, a atriz Andrea Beltrão, que, na novela "Um Lugar ao Sol", personifica uma mulher de meia idade, holofote midiático sob o qual supostamente se autorizariam todo tipo de invasão da intimidade da mulher.

Oras, fiquei me perguntando, será que todas as mulheres se sentiram à vontade e ou realmente representadas pelo teor da

\footnotetext{
1 Texto publicado originalmente no FACEBOOK - Blog Fala Sério!, disponível no link: https://www.facebook.com/marcelo.pessoa.9480/posts/10209655354456614. Neste periódico, se insere como "Produção Textual Livre", no LATTES, na lacuna "Outras Produções Bibliográficas" e assim, portanto, sem a pretensão de produzir Ciência, stricto sensu.

${ }^{2}$ Bolsista de Produtividade Científica - Chamada 01/2021 - Programa de Bolsas de Produtividade em Pesquisa - PQ / UEMG.
} 
reportagem? Será que este tema da intimidade feminina não encontraria outros fóruns mais apropriados para o adequado debate e reflexão - tais quais seriam os grupos femininos, os clubes de serviço e ONGs, redes de contatos particulares dos próprios interessados no assunto, ambientes de aconselhamento terapêutico, a família e, especialmente, a conversa a dois e entre quatro paredes ou, como pode ser o caso concreto, ainda que consigo mesma?

Vejam, eu fiquei com estas indagações na mente, não por que eu seja Conservador ou que cultive algum viés retrógrado em relação à quebra de tabus, preconceitos e congêneres. O que me causou estranhamento, foi o fato de que, se para quaisquer das perguntas que menciono aqui, a resposta for "sim", daí, então, teríamos que lidar com esta exposição excessiva como sendo, de fato, o eixo do problema que aqui discuto. Do contrário, não haverá razão alguma que alimente meu discurso, tornando desnecessário, também, este texto.

Certos aspectos da sexualidade feminina, masculina, LGBTQIA+, acredito, dizem respeito ao que é particular, íntimo, restrito a cada um e, no máximo, ao seu parceiro (a), ainda que esta parceria se dê no ludismo da própria imaginação.

Logo, tornar o que é particular e íntimo em algo público e escancarado não me pareceu exatamente "educado" ou "respeitador" para com as mulheres, para com ninguém, confesso. Mas, reforço, isso é só uma impressão minha.

$E$, além disso, o que ficou bem evidente para mim, é que a GLOBO, durante a matéria supra, estaria muito mais preocupada em requentar a audiência da novela citada, do que, de fato, interessada em alimentar com ingredientes sérios um "debate" sobre a intimidade do ser humano, a qual, aliás, é protegida, no Brasil, pela Constituição de 1988, Artigo $5^{\circ}$, Inciso X: "são invioláveis a intimidade, a vida privada, a honra e 


\section{AKEDIA}

a imagem das pessoas, assegurado o direito a indenização pelo dano material ou moral decorrente de sua violação".

Prezados, a masturbação feminina ou de quem quer que seja, é de tanto interesse público quanto possam ser a constipação intestinal, a congestão nasal, a cólica renal, o mau hálito etc. Ou seja, nenhum.

Nada, portanto, justifica a violação da intimidade, o que, além de conduta grosseira, de péssimo gosto, é inconstitucional e deveria ser objeto de profunda indignação a ser manifesta pelo STF e, sobretudo, pelas mulheres e por todos os organismos que se propõem a defende-las quando seus direitos e integridade são violados ou ameaçados. 